\section{Dangers of lubricants used with condoms}

SiR-Most condoms are used for contraceptive purposes. Recently, however, their use has been widely promoted to help

- showed a similar pattern, with reductions of up to $95 \%$ from initial values.

Clearly, users of latex condoms should

Mean percentage loss in tensile strength $(n=10)$

\begin{tabular}{lccccccc}
\hline & \multicolumn{3}{c}{ 'LUBRICANT' } & \multicolumn{2}{c}{ Corn oil } \\
& \multicolumn{2}{c}{ Baby oil } & \multicolumn{2}{c}{ Petroleum jelly } & \multicolumn{2}{c}{ Cor } \\
& $15 \mathrm{~min}$ & $60 \mathrm{~min}$ & $15 \mathrm{~min}$ & $60 \mathrm{~min}$ & $15 \mathrm{~min}$ & $60 \mathrm{~min}$ \\
Durex (FRG) & 92 & 91 & 70 & 69 & 74 & 68 \\
Durex Elite (UK) & 92 & 92 & 52 & 64 & 71 & 72 \\
Lifestyles Nuda (UK) & 73 & 77 & 51 & 61 & 64 & 73 \\
Lifestyles Nuda (USA) & 69 & 76 & 62 & 71 & 64 & 67 \\
Mates (UK) & 68 & 84 & 45 & 65 & 63 & 68 \\
Ramses Extra (USA) & 93 & 93 & 75 & 80 & 77 & 78 \\
Trojan Extra (USA) & 91 & 93 & 82 & 83 & 71 & 79 \\
Duo (Netherlands) & 91 & 90 & 55 & 63 & 55 & 80 \\
Lifestyles Extra (UK) & 76 & 84 & 35 & 53 & 39 & 65 \\
Lifestyles Extra (USA) & 76 & 84 & 41 & 67 & 65 & 70 \\
Mates Tough (UK) & 76 & 84 & 43 & 67 & 58 & 67 \\
\hline
\end{tabular}

limit the spread of sexually transmitted diseases, especially AIDS ${ }^{\prime}$. Many studies show that condoms are an effective barrier to the causative microorganisms ${ }^{2}$.

It is widely held that petroleum- or oilbased lubricants such as baby oil, petroleum jelly or corn oil should not be used with latex condoms. Some manufacturers warn against such use on their packaging. Unable to find any published data to support this view, we tested major brands of latex condoms and samples of lubricants.

Each condom unpacked and exposed to oils at $37^{\circ} \mathrm{C}$. After exposure, the tensile strength of the condoms suffered major, and often drastic, losses after a short period (see table).

Other physical properties - elongation at break, burst pressure and burst volume not use additional lucricants that are petroleum- or vegetable-oil based, or else their condoms are very likely to fail. On the other hand, three water-based lubricant products we have tested, Duragel, Duracreme and Senselle, do not adversely affect the physical properties of condoms

Nick White KAREN TAYLOR

ADRIAN LYSZKOWSK JOHN TULLETT COLIN MORRIS

London International Group,

Research and Development, Unit 205, Cambridge Science Park, Cambridge CB4 4GZ, UK

1. Koop. C.E. J. Am. med. Ass. 256, 2784-2789 (1986) 2. J. Am. med. Ass. 259. 1925-1927 (1988)

\section{Evolution of the early angiosperm groups}

SIR-Chris Humphries (Nature 333, 300$301 ; 1988)$ gives an interesting commentry on the phylogenetic classification of the angiosperm subclass Hamamelidae. He recognizes the role that the palacontological record can play but states that the study of systematic patterns will probably be more significant for understanding the early evolution of this and other angiosperm groups.

In arguing this point, Humphries paraphrases comments that I made (Nature 331, 304-305; 1988) about the nature of the fossil record of early angiosperms. In doing so, he unfortunately misrepresents me, presenting a view diametrically opposed to what I actually said. Rather than claim that the "processes by which angiosperms came to dominate low-land sediment-accumulating habitats are the most important for understanding angiosperm radiations," I said that floras from these habitats are the only ones well represented in the fossil record and for this reason palaeontological evidence alone cannot give a comprehensive picture of the radiation of the angiosperms. This was one of my main criticisms of Lidgard and Crane's analysis of the fossil record (Nature 331, 344-346; 1988) which in my view was making wide-ranging claims about early angiosperm radiation that are not justified by the nature of the data.

Lipscombe Close,

Christopher J. Cleal

Newbury, Berkshire RG14 5JW, UK

\section{Image-processing packages}

SIR-Kendall Preston (Nature, 333, 611612 ; 1988) makes the valid point that the number of different image-processing software packages, and the lack of standards in data format, have produced much extra work and programming for researchers. His final point concerns the problem of machine specificity, where imageprocessing packages are wedded to particular hardware. Here, I think, the article is misleading on current trends in image processing. The UNIX operating system and the $\mathrm{C}$ language are becoming very prevalent in the image-processing community, making it possible to create truly portable image-processing packages. Several are currently available, including the one I wrote and distribute, called HIPS (Landy, M.S., Cohen, Y. \& Sperling, G. Comp. Vision Graphics Image Process. 25, 331-347; 1984), which is used on many different machines.

Department of Psychology,

Michael Landy

New York University,

6 Washington Place,

New York, New York 10003, USA

\section{Latex gloves not enough to exclude viruses}

SIR-We have examined latex gloves from four manufacturers using scanning electron microscopy and energy dispersive $\mathrm{X}$ ray analysis. All of the gloves had pits $3-$ $15 \mu \mathrm{m}$ wide and up to $30 \mu \mathrm{m}$ deep on both interior and exterior surfaces. Irregular particles $(30-50 \mu \mathrm{m})$ containing silicon and magnesium were embedded in the latex deeply enough to cause pits themselves. Freeze-fractured sections of all gloves showed cavities throughout the matrix and tortuous channels $(5 \mu \mathrm{m})$ penetrated the entire thickness of the glove (see figure). Despite a recent report that gloves exclude virus cultures (Dalgleish, A.G. \& Malkousky, M. Brit.
J. surg. 76, 171-172; 1988), our findings suggest that double gloving, possibly supplemented by a surfactant/viricide, is a prudent expedient for those handling HIV or hepatitis B virus-infected material.

SUSAN G. ARNOLD

JAMES E. WHITMAN JR

Advanced Biotechnologies,

2150 Tech Road, Silver Spring,

Madison 20904, USA

CECIL H. Fox

Michele H. CotTler-Fox

National Institutes of Health,

Bethesda, Maryland 20892

and

Department of Medicine,

Georgetown University Hospital, Washington, DC 20057, USA

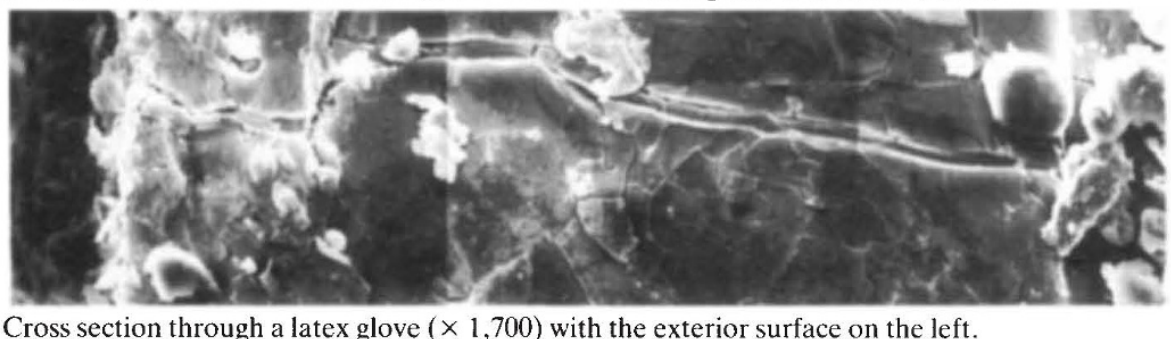

